Document downloaded from:

http://hdl.handle.net/10251/127192

This paper must be cited as:

Weckowska, DM.; Molas-Gallart, J.; Tang, P.; Twigg, D.; Castro-Martínez, E.; Kijenska Dabrowska, I.; Libaers, D.... (2018). University patenting and technology commercialization legal frameworks and the importance of local practice. R and D Management. 48(1):88-108.

https://doi.org/10.1111/radm.12123

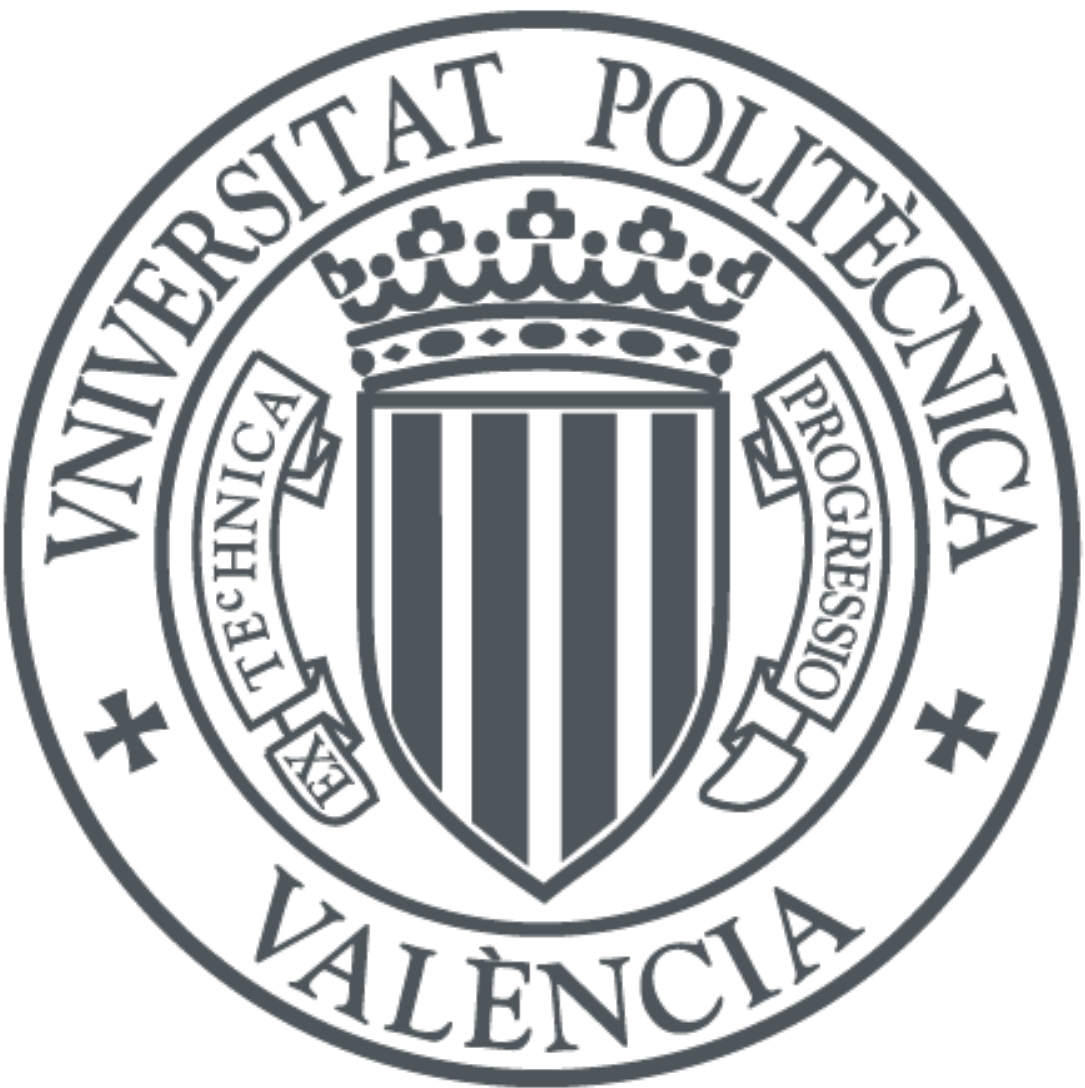

The final publication is available at

http://doi.org/10.1111/radm.12123

Copyright Blackwell Publishing

Additional Information 


\title{
University Patenting and Technology Commercialization - Legal Frameworks and the Importance of Local Practice
}

\begin{abstract}
The impact of national legislative frameworks on the higher education sector's contribution to technological innovation is heavily disputed. This paper argues that legislative frameworks may stimulate the development of local practices for the management and exploitation of intellectual property (IP), which, in turn, determine the level of academic patenting. We present case studies of two comparable universities in each of four selected European countries with different histories of national IP legislation. A within-country analysis shows that a wider range and earlier development of local IP management and exploitation practices are accompanied by higher levels of academic patenting, and that increasing similarity of IP practices is associated with decreasing differences in patenting outputs. A preliminary cross-country analysis reveals an expansion in and increasing similarity of practices for IP management and exploitation in countries with different national IP framework histories. We conclude that adopting Bayh-Dole-like legislation may trigger the development of local IP practices, which stimulate patenting. However, it is not always sufficient and definitely not always necessary. The study concludes with some policy recommendations.
\end{abstract}




\section{Introduction}

University patenting has been heralded as a symbol of the changing relations between universities and their socio-economic environments. The Bayh-Dole Act enacted in the US in 1980, has served as a model to facilitate university patenting and promote the commercialization of university research, and has been imitated by numerous countries (Mowery, 1998, Mowery et al., 2001, Rafferty, 2008). The (relative) impact of legislative framework conditions (Bayh-Dole in the US and similar legislation introduced in many European countries) on the university sector's contribution to technological innovation is still heavily debated (Grimaldi et al., 2011, Kenney and Patton, 2011).

Two schools of thought appear to have emerged: one that seems to follow the argument that Bayh-Dole type regulations positively affect university patenting output (Goldfarb and Henrekson, 2003, The Economist, 2002, OECD, 2003, Siepmann, 2004), and another that is very sceptical and sees little need for US-style intellectual property (IP) regulations within the public research sector (Mendes and Liyanage, 2002, Mowery and Sampat, 2005, Baldini et al., 2006, Baldini, 2009). We argue that national legislative frameworks may stimulate the development of local practices for the management and exploitation of IP, which, in turn, are important for determining the level and quality of patenting activity. Thus, the relevance of national legislative frameworks is twofold. First, they signal the legitimacy of academic patenting activities; second, they signal the importance of developing local IP management and exploitation practices, including services such as intellectual property rights (IPR) counselling, market analysis, IP exploitation and incubation.

Baldini (2006) notes that in Europe the attention on academic patenting is a relatively new phenomenon and has recently been examined by scholars in diverse national settings (e.g. Azagra Caro et al., 2003, Goldfarb and Henrekson, 2003, Henrekson and Rosenberg, 2001, Meyer et al., 2003, Van Looy et al., 2004, Wallmark, 1997). However, Baldini points out that there are no cross-national studies on academic patenting. He observes also that although some studies try to assess how legislative and organizational changes interact with local context specificities (e.g. Baldini et al., 2006, Henrekson and Rosenberg, 2001, JonesEvans et al., 1999), further work is needed to provide a much richer understanding of the intertwined roles of national legislation and local practices in stimulating the rate and quality of academic patenting. 
This study is a first attempt to fill this gap in the academic patenting literature. It investigates whether national legislation can stimulate the development of local practices for managing and exploiting IP, which, in turn, affect the level of patenting activity, by addressing two research questions: (1) How do local practices for IP management and exploitation affect academic patenting rates? (2) How does the national IP legislative framework affect local IP management and exploitation practices? We focus on universityowned patents as a metric of academic patenting, but acknowledge that there is a need to understand the relative importance of national legislation and local practices for other patenting metrics (i.e. university-invented patents) and other modes of knowledge transfer (e.g. collaborative research or spin-outs).

We explore the impact of local practices on academic patenting (which addresses the first research question) by examining whether changes to local practices correspond to changes in academic patenting rates at comparable universities within the same country, that is, within the same legislative framework. Within-country analysis reveals that universities with a wider range of activities to support research commercialization, and earlier development of these practices, have higher rates of patenting. We observe also that increasing similarity of local practices for IP management and exploitation is associated with decreasing differences in patenting outputs. We conclude that local IP practices are an important determinant of patenting rates.

To investigate the effect of legislative frameworks on local IP practices (which addresses the second research question) we conduct a within-country analysis of the timing of changes to national legislation and local practices in universities in four European countries, and a preliminary cross-country analysis comparing the development of local practices across four countries with different national IP legislation histories. We find that comparable universities within the same country develop IP management and exploitation practices at different paces - before, shortly after or long after the legislative change to institutional IP ownership. Moreover, development of an increasingly wider range of similar IP practices is found across countries that shifted to institutional IP ownership and a country that retained 'professor's privilege' legislation. We conclude that a shift to Bayh-Dole type legislation may stimulate the development of local practices for IP management and exploitation, which, in turn, stimulate academic patenting, but that it is not always sufficient and definitely is not always necessary. 


\section{Literature review}

The literature on academic patenting has grown significantly since the 1990s (Van Zeebroeck et al., 2008). The level of interest in this topic is not surprising since, measured by the number of academic scientists listed as (co-)inventors on patents it seems that academic scientists are increasingly active in commercializing their scientific discoveries (Henderson et al., 1998, Lissoni et al., 2008, Meyer et al., 2003, Thursby and Thursby, 2002, etc.). This section briefly reviews the literature on national legislative frameworks governing university patenting and commercialization, and local university practices to facilitate commercial exploitation of academic research. We discuss the legislative framework in the US, and policies towards the commercialization of university research in Europe.

\subsection{The 1980 Bayh-Dole Act and its impact on academic patenting}

Before 1980, there was no uniform policy in the US regarding ownership of inventions developed by government contractors using federal funding and Schacht (2009) estimates that fewer than $5 \%$ of academic patents were effectively licensed to private firms for further commercialization. The interest of US government to address the issue of underutilization of government-owned IP developed by publicly funded government contractors and to promote technological innovation led to the enactment of the Bayh-Dole Act in 1980. This act enabled universities to claim title of ownership to inventions made using public funds, and to become directly involved in the commercial exploitation of these inventions (Mowery et al., 2002).

While the legislation created an overall framework to enhance the utilization of research results funded by public monies, questions were raised about the effectiveness of these arrangements (Nelson, 2004, Washburn, 2005). For instance, increased universityindustry collaboration might shape the direction of the research (Dasgupta and David, 1994, Martin, 2001), reduce the open sharing of scientific results (Dasgupta and David, 1994, Florida and Cohen, 1999), and put a greater emphasis on applied rather than basic research (Mowery and Ziedonis, 2002). However, a comprehensive review of academic patenting and its impacts on academic research concluded that the positive effects exceeded any potential negative impacts (Van Zeebroeck et al., 2008).

Apart from these initial concerns, the Bayh-Dole Act has been viewed as particularly successful in attaining its objectives. However, the increase in academic patenting cannot be attributed only to changes in IPR legislation. The passage of the Bayh-Dole Act was 
accompanied by the development of organizational arrangements to identify, manage and effectively exploit inventions made and disclosed by faculty. It provided an impetus to professionalize technology transfer operations within academia. However, it should be noted that, although university researchers are required by law to disclose inventions and to assign their discoveries to their employing university, the monitoring and enforcement of these requirements are difficult (Siegel et al., 2003, Fini et al., 2010). Problems related to enforcement of the Bayh-Dole Act suggest that local organizational practices may matter as much as changes to the national legislative framework. Some recent research stresses the importance of local organizational arrangements and practices for the successful commercialization of academic research (Grimaldi et al., 2011, Nelson, 2014).

\subsection{The IPR regulations in Europe and the importance of local practices}

In recent decades, many European governments have been actively promoting academic patenting in an effort to enhance the utilization of industry-relevant scientific research and contribute to economic development, job creation and resource generation. Some European countries have had Bayh-Dole-like regulation in place for about 30 years, for example, France (Della Malva et al., 2013) and Spain (Azagra-Caro, 2010). In France, university ownership of patents based on inventions sponsored by public funding was put in place in 1984 (Public Law 84-52), although enforcement of institutional ownership has been weak (giving inventors plenty of leeway to manage the IP associated with their inventions). None of the legislative interventions in Europe have been considered by law makers to be successful (Della Malva et al., 2013, Geuna and Rossi, 2011). The French government enacted the 1999 Innovation Act to increase IP awareness within universities and to increase patenting rates and technology commercialization efforts. This legislation seems to have succeeded in making universities claim, manage and commercially exploit the IP developed by the academic scientists they employ (Della Malva et al., 2013). The Innovation Act includes several provisions related to the commercial exploitation of university IP as an explicit university mission, and the creation of internal Technology Transfer Offices (TTOs) to facilitate commercialization (Della Malva et al., 2013).

Other countries have been reassessing their IP laws with a view to encouraging IP ownership by the universities in which the research is performed (OECD, 2003), echoing the landmark Bayh-Dole Act (Baldini, 2006). For example, some countries with a long history of 'professor's privilege' systems, which allow individual academics to own and exploit the IP 
generated from publicly funded research, have introduced Bayh-Dole-like regulation. They include Denmark in 2000, Norway and Germany in 2002 and Finland in 2007. Also, some new EU member states in Eastern Europe - Poland in 1993, Slovak Republic in 2000, and Hungary in 2006 - have shifted from state to institutional ownership of IP. In 2014, Sweden is the only country in the EU with a strong 'professor's privilege' system (see e.g., Meyer et al., 2007).

Table 1 presents the rates for university-owned patents, for selected European countries. The data are drawn from Geuna and Rossi (2011), which provides a preliminary overview for the period 1998-2006. The data show a general upward trend in rates of university-owned patents in all countries with an institutional ownership system, for the whole period or some parts of it. Nevertheless, university-owned patents account for less than $20 \%$ of total patenting activity at European universities (Geuna and Nesta, 2006, Crespi et al., 2006) and probably even less in the case of Sweden. It is difficult to obtain a precise view of the total level of patenting activity involving universities given the difficulties of identifying inventor affiliations. Identification of university-owned patents is straightforward; identification of university-invented, but not owned patents is much harder (Meyer et al., 2003).

\section{INSERT TABLE 1 HERE}

The introduction of Bayh-Dole type regulation in EU countries has undoubtedly been important for boosting academic patenting. However, whether the increasing numbers of academic patents can be attributed solely to national legislative frameworks is questionable. Further, EU countries that have adopted such IP laws still appear to $\operatorname{lag}^{1}$ behind the US in terms of level of academic patenting per million dollars of funding, a result that might be due to differences in university-level internal mechanisms, that is, local practices (e.g. business plan competitions, entrepreneurship education, incubators, TTO governance and capabilities, university culture) (Grimaldi et al., 2011, Schoen et al., 2014). Other factors related to local practices include lack of incentives for faculty to engage in commercialization, lack of awareness among faculty about IPR and commercialization mechanisms, public sector pay

\footnotetext{
${ }^{1}$ Note that, even in the US, within the Bayh-Dole legislative framework, there are significant differences across universities in academic patenting rates and resulting royalties (Mowery et al., 2001), which again highlights the importance of local practices and conditions.
} 
scales that make it hard to recruit capable technology transfer personnel, and lack of commercializable results from some research universities (Wright et al., 2008). Studies show that academic patenting also is determined by the presence of an engineering discipline at the university, the level of scientific productivity and the size of the university (Van Looy et al., 2011). Below we discuss some evidence suggesting that local IP management and exploitation practices have an equally if not more important impact on university patenting and technology transfer output than legislative frameworks.

First, Table 1 shows university patenting increased in countries that introduced BayhDole-like regulation in the early 2000s (e.g. Germany, Austria, Norway) as well as in countries that have had such regulation in place since the 1980s, such as the UK and Spain. In the UK, universities have been entitled to ownership of the IP created by their employees since the 1977 Patent Act, yet Table 1 shows a weak increase in rates of university-owned patents at the turn of this century. This increase cannot be attributed to changes in IPR legislation. Rather, it is related to specific policy instruments introduced by government to stimulate the commercialization of academic research. An example is the Higher Education Innovation Fund ${ }^{2}$ introduced in the late 1990s to support building knowledge transfer capacity in UK universities (Lambert, 2003, Meyer and Tang, 2007).

Second, rates of academic patenting have increased in Sweden which has operated a 'professor's privilege' system since 1949, which suggests that factors other than legislation are responsible for this growth. Taking account of university-owned and university-invented patents, Lissoni et al. (2008) show that there were more than twice as many academic patents in the period 1994-2002 as in 1978-1993. Sellenthin (2009) shows that Swedish academics are more likely to engage in patenting if they are supported by a TTO, highlighting the importance of local practices.

Third, considerable differences in academic patenting rates among comparable institutions in the same country point to the importance of local practices rather than national legislative frameworks. More specifically, the national legislative framework sets uniform ground rules for IP ownership, management and commercial exploitation. However, differences in academic patenting rates may be due to how (and when) universities organize themselves internally, build the appropriate capabilities, and provide the proper leadership to take full advantage of these regulations to maximize commercial exploitation (Siegel and

\footnotetext{
${ }^{2}$ This funding scheme was initially called the 'Higher Education Reach-out to Business and Community'.
} 
Phan, 2005). Figure 1 summarizes patenting activity in four leading non-US universities. Patenting rates in Oxford University from the mid-1990s to the mid-2000s are substantially higher than in Cambridge University. This reflects the very different approaches to IP management at these two leading UK universities during this period. Oxford University has had a TTO since 1987; Cambridge University established a single centralized unit responsible for the commercialization of academic research only in 2005, following several structural and organizational reforms (Breznitz, 2010). Also, university IP policies differed. Up to 1998, IP related to Cambridge was not automatically assigned to the university and, in many cases, the research sponsor or the faculty assumed ownership (Minshall et al., 2004). After successive changes in Cambridge's IP policies, first in 2001, and later in 2005, the university enforced full control over inventions, regardless of their funding source (Breznitz, 2010). In contrast, Oxford has organized its technology transfer activities in a separate unit (ISIS) since 1987, and since had a more stable IPR policy than Cambridge (Lawton-Smith, 2003). The differences in the patenting rates of these two universities (see Figure 1) suggest that national legislative frameworks can have an impact on patenting rates only if they are accompanied by supportive local practices for IP management and exploitation.

\section{INSERT FIGURE 1 HERE}

Finally, some scholars argue that attempts to imitate Bayh-Dole Act regulation is unlikely to increase technology transfer to the same extent as in the US (Mowery and Sampat, 2005). They conclude that 'efforts at emulation of the Bayh-Dole policy elsewhere in the OECD are likely to have modest success at best without greater attention to the underlying structural differences among the higher education systems of these nations' (Mowery and Sampat, 2005, p.123). Similarly, Baldini (2006, p.197), in his review of 125 contributions to the university technology transfer area, concludes that 'university patenting and related activities need a fertile context to develop both inside and outside the campus'.

\subsection{IP management and exploitation practices}

The studies discussed above indicate clearly that the organizational practices for IP management and exploitation may be an important factor determining the rate of university patenting. This section reviews studies that shed some light on the organizational arrangements for technology transfer. 
The importance and role of centralized organizational units that provide support for the commercialization of academic research continue to be debated. The increasing rates of academic patenting have been accompanied by the creation of university TTOs. However, some studies of EU countries do not confirm a positive effect of TTOs on the commercialization of academic research (see Goldfarb and Henrekson, 2003 for Sweden, Muscio, 2010 for Italy, Saragossi and van Pottelsberghe de la Potterie, 2003 for Belgium, Sellenthin, 2009 for Germany and Sweden). TTO practices seem to matter more than the mere presence of a TTO, as suggested by Hülsbeck et al. (2011), which shows that lack of a clear division of labour and specialization of tasks within TTOs decreases the number of invention disclosures. In addition, TTO governance may have a significant impact on academic patenting and commercialization activities (Schoen et al., 2014).

The first limitation of existing work on the organizational practices related to technology transfer is its focus on single countries. This methodological approach does not allow a thorough exploration of the interplay between legislative frameworks and organizational practices for fostering the commercialization of academic research. It is also not clear whether similar practices can be developed under different legislative frameworks and whether the effect of such practices on patenting rates is comparable. Second, previous studies tend to focus on the role of the TTO. However, Clark (1998) argues that the presence of a TTO is only one of many characteristics of an entrepreneurial university. The present study tries to overcome the shortcomings of previous work by adopting Clark's (1998) concepts of strengthened steering core, expanded developmental periphery (e.g. professionalized outreach offices, incubators and outward-reaching research centres), and diversified funding base, to explore the importance of IP management and exploitation practices for stimulating the commercialization of scientific discoveries, in a number of European countries with different histories of national legislations. Applying Clark's framework adds to our understanding of the importance of local university patenting practices and related activities, in countries with different national legislative frameworks (Mathieu et al., 2008). 


\section{Method}

\subsection{General approach}

Our study is concerned with exploring the similarities and differences in academic patenting and local IP practices and their potential link to legislative frameworks. These frameworks changed considerably in many European countries in the 1990s and early 2000s. We adopt a case study approach because it is particularly suitable to explore how academic patenting is affected by evolving IP management and exploitation practices in countries with different legislative frameworks. This research strategy allows us to use multiple sources and types of data and to take account of contextual complexity (Yin, 2009), which is particularly important in cross-country studies. In order to address the research questions, we examine differences between two comparable institutions in the same country, for four selected EU countries.

\subsection{Case study selection}

We need a selection of cases studies that allows for analysis of (1) the relation between national legislative frameworks and local practices, and (2) the relation between local practices and academic patenting in order to conduct an empirical examination of the proposition that national legislative frameworks can stimulate the development of practices for managing and exploiting IP, which in turn stimulate academic patenting.

\subsubsection{Selection of countries}

While this study is limited in scope and scale, we have tried to select cases that reflect the diversity of the different legislative frameworks as well as the geography. Our research draws on an initial study supported in part by the European Patent Office (EPO) which collected basic information on IP frameworks in European countries (Meyer et al., 2007), and categorized countries using two criteria: (1) whether a country has changed their IP legislation since the 1990s, (2) whether a country has currently institutional ownership of IP from academic research or a 'professor's privilege' model.

Some countries have made no legislative changes since the 1990s and apply Bayh-Dolelike legislation (e.g. the UK, Spain, Turkey, Belgium (Flanders)) or professor's privilege (Sweden). Other countries have changed to institutional ownership from a professor's privilege system (e.g. Germany, Austria, Finland, Denmark, Italy) or a state ownership of IP from publicly funded research (e.g. Poland, Hungary). 
We selected countries from each category. The objective was that the countries studied included representatives covering the above categories and offer a balanced geographic spread. Our initial study (Meyer et al., 2007) included Western and Northern European and Eastern and Southern European countries; specifically: the UK, Germany, Sweden, Spain, Poland and Turkey (the last is an EPO member state) $)^{3}$.

This paper focuses on four of these countries - Spain, Sweden, Germany and Poland because of the size constraints for a journal article. This selection includes countries with different IPR regulation histories, ensures representation across all above categories and the geographic spread. More importantly, it allows us to examine the relation between national IP legislative frameworks and local practices for IP management and exploitation. Two university cases were identified for each of these countries.

\subsubsection{Selection of university cases}

The selection of university cases (i.e. universities) followed a purposive sampling approach. We aimed to select two universities in a given country that share as many characteristics as possible but exhibit differences in IP practices. For this case selection approach to be effective we relied on country rapporteurs with expert understanding of the respective national contexts (incl. the respective countries' higher education systems, IPR, university-industry collaboration, and technology transfer arrangements). The rapporteurs were asked to identify universities in their countries that exhibited the greatest possible similarity in terms of size, type and disciplinary and subject coverage ${ }^{4}$ and then to select a pair with different approaches to IPR and entrepreneurship, in line with Yin's (2009) idea of contrasting cases.

The case selection strategy allows us to explore the extent of differentiation or variation in the universities' patenting rates and IP management and exploitation practices, within a specific legal framework, with the universities' other characteristics being as similar as possible. More importantly, it allows us to examine whether similar universities develop similar practices in response to changes (or not) in national legislations, and whether particular practices can be identified that might explain differences in the patenting outputs of otherwise similar universities.

\footnotetext{
${ }^{3}$ The authors also studied cases in Belgium and Finland.

${ }^{4}$ In particular, this includes a similar focus on broad subject areas and disciplines. The aim is to compare universities that are broadly similar in their general characteristics. For instance, if one university has a strong life-science/biotech focus then we would seek to include a comparator with the same orientation (rather than an institution with an engineering or 'polytechnic' emphasis).
} 


\subsection{Data gathering and analysis}

We tried to gather comparable information on universities' patenting outputs within and across countries. This was not always possible due to cross-university and cross-country differences in approaches to collecting data on academic patenting. The patenting outputs indicators used in this study include patent applications, patents granted, and income from exploitation of university IP. When possible, comparisons were made on the basis of normalized data. Patenting and other IP output data were normalized according to personnel data, that is, full-time equivalent faculty/academic staff ${ }^{5}$. The data on universities was collected in two rounds in 2006/7 and 2012/13. We followed a data collection template that was informed by our literature review (see appendix).

Two kinds of comparison were made to analyse the data. First, to achieve an improved understanding of the role of national legislative frameworks for stimulating academic patenting within countries, we examine the temporal correspondence between changes to national legislation and changes to local practices and then explore whether the observed changes in local IP management and exploitation practices are related to changes in the patenting outputs of comparable universities within each country.

Second, within the limits of the available data, we conduct some preliminary analysis of similarities and differences in practices across countries, over time, to gain further insights into the role of national legislative frameworks for stimulating commercial exploitation of academic inventions. The idea behind time period comparison is to explore whether there is a convergence in the selected universities' practices to support technology transfer, over a longer time period, despite their operating in countries with different national legislation traditions. Comparison of patenting rates across countries was impossible due to limitations related to the available patenting data.

\subsection{Limitations}

While we tried to ensure the greatest possible similarity of comparator universities across a range of features within the countries, our research would have benefited from greater comparability of universities across countries. For instance, the inclusion of a set of biotech or life sciences focused institutions and more engineering or 'polytechnic' universities in the countries studied would have allowed us to make more robust observations on similarities and differences within a discipline across countries. Based on the kind of data we collected

\footnotetext{
${ }^{5}$ If possible, we also refer to information on patenting by technological area/sector.
} 
care is needed in drawing conclusions. Therefore, we use cross-country comparisons in our discussion of the findings with the aim primarily of generating propositions for follow-up research.

Also, a greater variety of comparative cases also within countries would have been beneficial. Analysis of several institutional pairs (or groups of universities) would have allowed more comprehensive study of the actors and practices in a given country and might have provided a stronger sense of whether the extent of the differences observed varied by the organization's orientation or subject focus. While this is a shortcoming we readily acknowledge, and is an area for future research, we feel that in a piece of exploratory research the purposive case selection approach chosen allows some relevant observations in relation to legal frameworks and local practice.

\section{Comparative analysis within four European countries}

\subsection{Case studies of two Spanish universities}

The legal framework under which Spanish universities and research institutions operated has changed substantially during 1980s. The Ley Orgánica 11/1983 de Reforma Universitaria or University Reform Act (URA) gave Spanish universities autonomy to manage their budgets and assets, including patents (art.3). The URA also, for the first time, allowed universities to forge contracts with third parties for scientific, technical and artistic work (art. 11). The Patents Act of 1986 (Act 11/1986) bestows ownership of academics' inventions on their university, establishing a framework for the distribution of the revenue obtained from their exploitation, and recognizing the rights of academics to have a share of this revenue (art. 20). However, the Patents Act does not specify the percentage of inventors' share. Note also that at the end of 2011 a new Science Technology and Innovation Law was enacted that obliges public sector employees to inform their organization (university, research establishment) about their research results and to collaborate in the process of their protection and transfer (art. 15).

This section compares changes to IP practices and patenting outputs in two traditional Spanish universities - Universidad de Valladolid (UVA) and Universidad de Santiago de Compostela (USC) - which expanded to include technical disciplines in the early 1980s. Although these universities operate within the same IPR legislative framework and are comparable in size and research income, their approaches to the commercialization of 
academic research have differed throughout the 1990s and early 2000s (see Table 2). Three years after shifting to a Bayh-Dole type legislative framework, both universities set up outreach offices and introduced IP policies, which shows that a legislative change successfully signalled the importance of developing local support for technology transfer. However, only USC subsequently developed proactive IP management and exploitation practices. UVA only began to introduce a systematic approach to IP management and support for company formation in late 2000s - more than 20 years after the legislative shift. These cases show that policy instruments may stimulate the development of organizational units, but are not always effective at promoting the development of supportive local practices for IP management.

The USC, characterized by earlier development of IP management and exploitation practices, has substantially higher patenting output and higher patenting revenues than UVA. In 2006, USC had five times more patent applications than UVA. Although growth in patenting at UVA was steeper than at USC in the late 2000s, USC still outperformed UVA in 2010, with almost double the number of applications. Decreasing differences in (normalized) patenting output arguably are associated with increasing similarity of local practices for IP exploitation since about 2007. UVA embarked on activities that had been in place in USC for some time including more proactive IP management and support for spin-outs. These findings indicate that local practices are important determinants of academic patenting.

\section{INSERT TABLE 2 HERE}

\subsection{Case studies of two German universities}

Two pieces of national legislation regulate the commercialization of publicly-funded research in Germany. The Employee Invention Law (Gesetz über Arbeitnehmererfindungen) conferring institutional ownership of inventions created by employees in the course of their normal duties has applied to university employees since 2002 when the exemption granting professor's privilege was removed. The Law specifies that $30 \%$ of the gross revenues should go to the inventor (art. 42). The Higher Education Framework of 2005 (Hochschulrahmengesetz) makes technology transfer a university duty and states that 'the institutions of higher education shall promote the transfer of knowledge and technology'. 
Two of the country's most renowned technical universities are compared in this section TU Munich (TUM) and TU Berlin (TUB). Both universities are long established, and have excellent research records. Both participated successfully in the Exzellenzinitiative, a competition for funding and status. ${ }^{6}$ While both are leading institutions and operate within the same legislative framework, we can identify differences in their local practices (see Table 3).

In this context, it is interesting that both universities have undergone substantial processes of transformation. At TUM, the reforms started in 1995 and were linked closely to the university's president, Wolfgang A. Herrmann. The reforms embrace a new philosophy that views TUM as an 'entrepreneurial university', and cover a wide range of areas, including the effective management and exploitation of university IP. The emerging 'enhanced developmental periphery' should be seen in this context. While TUM had developed a strong support infrastructure a few years before professor's privilege was abandoned, this occurred as part of a wide ranging change. This case illustrates that a shift to Bayh-Dole type legislation is not necessary for the development of local practices to support technology transfer. TUB has also a long tradition of entrepreneurship and was the launch pad for the first incubator in Germany in the mid-1980s, but has undergone a process of strategic change to increase entrepreneurialism more recently. One year before the shift in national IP legislation, TUB entered a collaboration with a regional patenting agency, but dedicated internal units to manage and exploit IP were not set up until the late 2000s and cannot be attributed purely to the legislative change.

We can also identify differences between the approaches to patenting in these universities. TUM offers a broader range of subjects and has a somewhat larger faculty. For this reason, we focus comparison of patenting activity on areas where both are active. Normalized comparisons in the initial period point to higher output from TUM, almost twice that of TUB across most areas. While patenting activity has grown in the late 2000s in both universities, TUB's growth was steeper and patenting activity has almost doubled in some areas. It should be noted that this growth at TUB occurred well after the change in legislation, during the time of development of internal units to manage IP commercialization. TUM still performed slightly better than TUB in the more recent period, but the differences in patenting activity have decreased as practices have become more similar across these two universities since the recent changes at TUB.

\footnotetext{
6 Excellence Initiative for Cutting-Edge Research at Institutions of Higher Education (2012) (http://www.bmbf.de/en/1321.php; accessed 6 June 2013)
} 


\section{INSERT TABLE 3 HERE}

\subsection{Case studies of two Polish universities}

A few legislative changes have been key to enabling commercialization of academic research in Poland. In 1992 changes were introduced to the 1972 Inventiveness Law, which was in place during the communist period dominated by a state ownership. Since 1993, IP created by employees during the course of their normal duties belongs to the employer, with no exceptions for professors (Act 1993. 4. 14, art. 20.2). This position was confirmed by the Industrial Property Law of 2000 (Act 2001. 49.508) which additionally, unlike the former acts, does not deem scientific discoveries unpatentable. Moreover the Higher Education Act of 2005 (Act 2005.164.1365), for the first time, allows universities to set up centres for technology transfer and incubators and to form spin-out companies but does not state clearly that transfer of technologies to industry is university duty (art.86, 86a, 86b). Without being prescriptive, the Act allows the universities to introduce policies regulating the rights and duties of academic inventors, their remuneration, commercialization procedures, and use of university property (e.g. facilities) during commercialization (art. 86c). These activities were not regulated prior to 2005 .

Our study compares two top technical universities in Poland - Warsaw University of Technology (WUT) and Wroclaw University of Technology (WrUT) - similar in size and range of subjects. Despite operating within the same legal framework, their approaches to supporting technology transfer differed until very recently (see Table 4). In the mid 1990s, in the course of WrUT's participation in the European project 'Bridging the Gap Between University and Industry', it set up the Wroclaw Centre for Technology Transfer (WCTT) just few years after a legislative shift to institutional ownership of IP. WCTT developed a professional approach to managing and exploiting IP and offered services to academics at WrUT and entrepreneurs in the region. Both WrUT and WUT brought in legal experts specialized in patenting and licensing contracts to their respective research offices in the late 1990s. The focus on legal matters was not an issue for WrUT-based academics who were referred to the WCTT to get help with commercial exploitation of IP. The situation was different at WUT where, despite transforming the patenting unit into the Centre for Technology Transfer in 2004, did not provide help to assess the commercial viability of 
inventions, marketing or exploitation strategies until around 2010 when the internal unit was restructured. WrUT set up an incubator one year after this activity was explicitly allowed by the Higher Education Act of 2005. WUT followed suit five years later. Besides expanding the developmental periphery, WrUT strengthened its steering core earlier than WUT by specifying percentage of inventors share of revenues in its IP policy in 1998 - 14 years before WUT did so. It appears that WrUT quickly exploited the shift to Bayh-Dole type legislation to maximize commercial exploitation of its research, but the legislative change was not sufficient to stimulate similar developments at WUT.

Despite similarities in size and subjects, patenting rates are higher at WrUT. Remarkably, the differences in patenting output between these two universities increased in the 2000s. In 2005, WrUT had 1.35 times more patent applications than WUT, and in 2011 WrUT's patenting output was 5.5 times greater. This arguably is due to the differences in local practices during the 1990s and most of the 2000s. Thus, proactive IP practices are an important determinant of academic patenting in the Polish context.

\section{INSERT TABLE 4 HERE}

\subsection{Case studies of two Swedish universities}

Under the professor's privilege system, Swedish university faculty have the right to own IP resulting from publicly funded research. This right is granted as an exemption to the Rights to Employee's Inventions Act of 1949 which generally confirms institutional ownership of IP created by employees.

In order to explore the development of practices for IP management and exploitation in a country with the professor's privilege system and no change to the legislation, we look at two oldest universities in Sweden - Uppsala University (UU) and Lund University (LU) - which have well-established technical disciplines and are comparable in size (see Table 5). In the late 1990s, both universities developed infrastructures for knowledge transfer and expanded the range of their activities supporting research commercialization. This development of the local infrastructure (e.g. Forskarpatent agencies and holding companies in the 1990s) was driven by a number of government programmes as opposed to changes to the legislation. Despite similarities in the 1990s, the evolution of local practices at LU and UU has differed. In the 2000s, the LU was more active than UU in developing internal IP management and 
exploitation practices. LU has taken a stronger strategic approach to commercialization, set up an internal TTO-like unit five years earlier, and has developed a wider range of support activities than UU. Also, LU co-founded a business incubator in 1983 while UU's incubator was not established until 2000.

Assessing the impact of local IP practices on academic patenting in Sweden is problematic since statistics on university-invented (not university-owned) patents are not readily available. Patents filed by local Forskarpatent agencies provide an approximation of patenting trends. The data show that the patenting rates of these two universities were similar in the 1990s when the universities' IP practices were also similar. However, in the 2000s, researchers from LU, who had access to more local IP management and exploitation services, patented in collaboration with local Forskarpatent agency significantly more than UU's researchers. However, both universities seem to be successful in stimulating formation of start-up companies. These cases suggest that a shift to Bayh-Dole type legislation is not necessary to stimulate development of supportive IP management and exploitation practices that stimulate academic patenting.

INSERT TABLE 5 HERE

\section{Comparative analysis across four European countries}

This section makes cross-country comparisons, combining the observations from countries that shifted to institutional ownership of IP since the 1990s (Germany and Poland) and countries that made no changes in that period and continued Bayh-Dole Act-like legislations (Spain) and legislation granting professor's privilege (Sweden). Table 6 summarizes the legislative frameworks for the four countries and shows that patenting outputs differ across similar universities operating within the same legislative framework. The within-country analysis presented in the previous section shows that universities characterized by earlier development of a wider range of activities supporting research commercialization, display higher rates of patenting than similar universities operating within the same legislative framework, suggesting that local practices are an important determinant of academic patenting. Here, we examine the role of legislative frameworks in stimulating the development of these important local practices, across four countries. The findings should be viewed in the light of the methodological limitations discussed earlier. 


\section{INSERT TABLE 6 HERE}

Figure 2 depicts the timing of legislative changes in relation to key developments in local technology transfer practices in the four countries, and enables some preliminary crosscountry comparisons. The comparative analysis provides four key insights into the effects of national legislations on development of local practices which are vital for stimulating academic patenting.

\section{INSERT FIGURE 2 HERE}

First, a move to Bayh-Dole Act-like legislation can effectively stimulate development of local IP management and exploitation practices in some universities (Spain - USC, Poland WrUB), but other universities develop active support for technology transfer long after the legislative changes, probably to catch up with their counterparts (Spain - UVA, Poland WUT, Germany - TUB). This suggests that a shift to institutional ownership is not always sufficient to trigger development of local practices which stimulate academic patenting. Second, development of supportive local practices can be observed before any shift to BayhDole type legislation (Germany - TUM) and in the country with continuous professor's privilege exemption (Sweden - LU and UU). This suggests that a shift to institutional ownership definitely is not always necessary to stimulate local IP practices enhancing the rates of academic patenting. Third, it should be noted that some universities in the selected countries developed a wide range of local IP management and exploitations activities in the 1990s (USC, TUM, WrUT, LU), while this did not happen in other universities until the late 2000s (UVA, TUB, WUT, UU) regardless of the timing of legislative changes. This observation implies that forces other than national legislative frameworks must have been driving the development of activities supporting research commercialization. Fourth, at the start of the 2010s the range of local practices for IP management and exploitation was very similar across countries with different national legislation histories, and included legal advice, IPR counselling and management, market analysis, IP marketing, financing (except TUB and WUT), company formation expertise (except TUB and WUT) and incubation

services. This convergence of local IP practices across countries suggests that shifting to 
Bayh-Dole type legislation does not necessarily provide the trigger for the development of local practices that stimulate academic patenting.

In summary, the cross-country comparisons suggest that the shift to Bayh-Dole type legislation may stimulate the development of local practices for IP management and exploitation, which, in turn, stimulate academic patenting, but it is not always sufficient, and definitely it is not always necessary.

\section{Discussion and conclusions}

The purpose of this paper is to contribute to the debate on the relative importance of national legislative frameworks for stimulating commercialization of IP generated by publicly funded research, by shedding light on the role of local IP management and exploitation practices in countries with different IPR regulation traditions.

First, our findings show the importance of local practices for IP management and exploitation. Analysis of the patenting outputs of comparable universities within the same country reveals that universities with a wider range of activities to support research commercialization, and earlier development of these practices, have higher rates of patenting. The Spanish and German cases show that differences in patenting output decrease as practices become more similar. Conversely, differences in patenting output increase as practices become more dissimilar, as illustrated by the Polish cases in the period 2005-2010 and Swedish cases since 2000s. This evidence suggests that local practices have a significant effect on research commercialization, measured by levels of university-owned patents. ${ }^{7}$ The importance of local practices for determining patenting rates explains the contradictory results in existing studies of the effects of TTOs on commercialization performance (positive effect: Link and Siegel, 2005, no effect: Lockett and Wright, 2005, negative effect: Chapple et al., 2005). Our findings show that TTOs with a reactive approach to IP exploitation are less effective for stimulating patenting than those with proactive practices. Thus, studies exploring the impact of organizational arrangements should look beyond the organizational infrastructure for technology transfer.

\footnotetext{
${ }^{7}$ Researchers in Swedish universities also engage in patenting activity. However, because of the different ownership situation, this is not always visible in patent statistics, but leads to considerable success in start-up foundation.
} 
Second, we found that the range of activities for IP management and exploitation expanded in countries that shifted to Bayh-Dole Act-like legislation (Germany, Poland) as well as in countries with a long tradition of institutional ownership (Spain) or professor's privilege (Sweden). Thus, expansion of local practices for IP management and exploitation which boost rates of academic patenting, occurs across different contexts of IPR legislation. Put differently, if IPR legislation and other policy instruments are not effective for stimulating the development of local practices for IP management and exploitation, the growth in patenting rates is likely to be limited. This evidence suggests that the Bayh-Dolelike legislation may have an important signalling effect for increased commercialization of publicly funded research, but this is not automatic. The shift to Bayh-Dole type legislation is not always sufficient and definitely is not always necessary to trigger the development of local IP practise. This is in line with other findings about the limited effect of mere emulation of the Bayh-Dole Act (Baldini, 2006, Mowery and Sampat, 2005). In certain instances, the development of Bayh-Dole type legislation even is to be considered the consequence of the successful, pro-active entrepreneurial leadership and actions by universities that serve as role models in the country. Nevertheless, the German experience indicates that strong and decisive leadership in universities can develop entrepreneurialism in universities by fostering what Clark (1998) aptly describes as 'stimulated academic heartlands'. With proactive IP practices at 'an enhanced developmental periphery', research activity can translate into patenting, start-up and licensing activity.

Third, based on the cross-national comparisons called for in Baldini (2006), we show that local practices become increasingly similar across selected EU countries. Specifically, all selected universities recognize commercialization as a strategic goal and have been extending the range of their support activities beyond help with contractual issues and IP protection. This trend cannot be explained by convergence in national IPR legislations. It is more likely that the increasing similarities in practices are the result of a process of imitation and peer-topeer learning among technology transfer managers both at a national and an international level. Baldini et al. (2010) find that the convergence in Italian university IP policies is attributable to such processes. Future studies could examine the extent of convergence in IP practices within and across countries. This convergence of practices does not preclude customization of the TTO model to a specific university, as suggested by Schoen et al. (2014). The convergence of IP practices within and across countries is logical since they are part of TT business models and TT related business practices that have developed globally. 
However, TTO model should be and should stay attuned to the science portfolio and the various (amongst others, cultural and organizational) path dependencies of a specific university. Hence, the need for a customized TTO model that embraces the best national and international IP practices available.

The findings from the case studies should be considered in light of the limitations of our research design. While the changes in patenting rates seem to relate to evolving local practices for IP management and exploitation, there is a possibility that changes in the organizational culture and attitudes of academics to knowledge transfer have also played a significant role. Therefore, further research is required on the unique impact of local IP practices for large samples of universities. Moreover, the limitations of available patenting data did not allow to analyse the relation between local IP practices and patenting outputs across countries with different histories of national legislative frameworks. When more comparable patenting data becomes available for European countries, future comparative studies could provide even stronger evidence of the superiority of local practices and proactive university leadership over national legislation for determining patenting rates, and measure the strength of these effects. Finally, our study focused on only one metric of patenting and only one mode of university-industry knowledge transfer. Future comparative studies could widen the scope of investigation by including university-invented as well as university-owned patents and other modes of knowledge transfer, such as collaborative research or spin-out activities.

The evidence from our study suggests that a change to IPR legislation on its own, is unlikely to suffice to affect rates of academic patenting. Similarly, government schemes that aim to develop organizational units supporting commercialization may have limited impacts if these units adopt a reactive approach to commercialization, and lack professionalism in IPR management. This implies that in order to stimulate commercialization of academic research policymakers should develop interventions that aim at the development of effective local practices for technology transfer. It seems that creating a legislative context that clarifies the IPRs within an academic context goes hand in hand with stimulating and creating effective TTOs. Hence, simultaneity is required in IP legislation and local IP management and exploitation practices in academia. This conclusion reinforces previous insights into the effective organization of the technology transfer function within universities (Debackere and Veugelers, 2005, Debackere, 2012). 


\section{Acknowledgements}

Part of this research was supported by the European Patent Office. Funding is gratefully acknowledged. The authors also wish to thank three anonymous reviewers for their helpful feedback.

\section{References}

Azagra Caro, J. M., Fernandez De Lucio, I., and Guttierez Gracia, A. (2003) University patents: output and input indicators ... of what? Research Evaluation, 12, 5-16

Azagra Caro, J.M. (2010). Do public research organizations own most patents invented by their staff? Science and Public Policy, 38, 237-250

Baldini, N. (2006) University patenting and licensing activity: a review of the literature. Research Evaluation, 15, 197-207.

Baldini, N. (2009) Implementing Bayh-Dole-like laws: Faculty problems and their impact on university patenting activity. Research Policy, 38, 1217-1224.

Baldini, N., Fini, R., Grimaldi, R., and Sobrero, M. (2010) Organisational change and the institutionalisation of university patenting activity in Italy (Available at http://dx.doi.org/10.2139/ssrn.1632430).

Baldini, N., Grimaldi, R., and Sobrero, M. (2006) Institutional changes and the commercialization of academic knowledge: A study of Italian universities' patenting activities between 1965 and 2002. Research Policy, 35, 518-532.

Breznitz, S. (2010). Improving or Impairing? Following Technology Transfer Changes at the University of Cambridge. Regional Studies, 45, 463-478.

Chapple, W., Lockett, A., Siegel, D., and Wright, M. (2005) Assessing the relative performance of U.K. university technology transfer offices: parametric and nonparametric evidence. Research Policy, 34, 369-384.

Clark, B. R. (1998) Creating Entrepreneurial Universities: Organizational Pathways of Transformation, Kidlington: Pergamon.

Crespi, G., Geuna, A., and Verspagen, B. (2006) University IPRs and knowledge transfer. Is the IPR ownership model more efficient? . SPRU Electronic Working Paper Series, Paper 154. Brighton.

Dasgupta, P. and David, P. A. (1994). Towards a new economics of science. Research Policy, 23, 487-521.

Debackere, K. and Veugelers, R. (2005). The role of academic technology transfer organizations in improving industry-science links. Research Policy, 34, 321-342.

Debackere, K. (2012). The TTO: a university engine transforming science into innovation. LERU Advice Paper 10, January 2012.

Della Malva, A., F. Lissoni, and Llerena, P. (2013). Institutional change and academic patenting: French universities and the Innovation Act of 1999. Journal of Evolutionary Economics, 23, 211-239.

Fini, R., Lacetera, N., and Shane, S. (2010) Inside or outside the IP system? Business creation in academia. Research Policy, 39, 1060-1069.

Florida, R., and Cohen, W. M. (1999) Engine or infrastructure? The university role in economic development. In: Branscomb, L. M., Kodama, F. and Florida, R. (eds.) 
Industrializing Knowledge: University-Industry Linkages in Japan and the United States. London: MIT Press.

Geuna, A., and Nesta, L. (2006) University patenting and its effect on academic research: The emerging European evidence. Research Policy, 35, 790-807.

Geuna, A., and Rossi, F. (2011) Changes to university IPR regulations in Europe and the impact on academic patenting. Research Policy, 40, 1068-1076.

Goldfarb, B., and Henrekson, M. (2003) Bottom-up versus top-down policies towards the commercialization of university intellectual property. Research Policy, 32, 639-658.

Grimaldi, R., Kenney, M., Siegel, D., and Wright, M. (2011) 30 years after Bayh-Dole: Reassessing academic entrepreneurship. Research Policy, 40, 1045-1057.

Henderson, R., Jaffe, A.B., Trajtenberg, M. (1998). Universities as a source of commercial technology. Review of Economics and Statistics 80 (1), 119-127.

Henrekson, M., and Rosenberg, N. (2001) Designing Efficient Institutions for Science-Based Entrepreneurship: Lesson from the US and Sweden. The Journal of Technology Transfer, 26, 207-231.

Hülsbeck, M., Lehmann, E., and Starnecker, A. (2011) Performance of technology transfer offices in Germany. The Journal of Technology Transfer, 36, 1-17.

Jones-Evans, D., Kloftsen, M., E. Andersson, and Pandya, D. (1999) Creating a bridge between university and industry in small European countries: The role of the Industrial Liason Office. R\&D Management, 29, 47-56.

Kenney, M., and Patton, D. (2011) Does inventor ownership encourage university researchderived entrepreneurship? A six university comparison. Research Policy, 40, 11001112.

Lambert, R. (2003) Lambert Review of Business-University Collaboration: Final Report. London: HM Treasury.

Lawton-Smith, H. (2003) Knowledge organizations and Local economic development: The cases of Oxford and Grenoble. Regional Studies, 37, 899-909.

Leydesdorff, L., and Meyer, M. (2010) The decline of university patenting and the end of the Bayh-Dole effect. Scientometrics, 83, 355-362.

Link, A., and Siegel, D. (2005) Generating science-based growth: an econometric analysis of the impact of organizational incentives on university-industry technology transfer. European Journal of Finance, 11, 169-181.

Lissoni, F., Llerena, P., McKelvey, M., and Sanditov, B. (2008) Academic patenting in Europe: new evidence from the KEINS database. Research Evaluation, 17, 87-102.

Lockett, A., and Wright, M. (2005) Resources, capabilities, risk capital and the creation of university spin-out companies. Research Policy, 34, 1043-1057.

Martin B. R. (2001) The changing social contract for science and the evolution of the university. In: Geuna, A., Salter, A. J., Steinmueller, W. E., and Hoffman, Y. E. (eds.) Science and Innovation: Rethinking the Rationales for Funding and Governance. Cheltenham: Edward Elgar Publishers.

Mathieu, A., Meyer, M., Van Pottelsberghe de la Potterie, B. (2008), Turning science into business: A case study of a major European research university. Science and Public Policy, 35, 669-679

Mendes, P., and Liyanage, S. (2002) Managing sponsored research rewards to industry and universities. International Journal of Technology Management, 24, 206-218.

Meyer, M., Sinilainen, T., and Utecht, J. (2003) Towards hybrid Triple Helix indicators: A study of university-related patents and a survey of academic inventors. Scientometrics, 58, 321-350. 
Meyer, M., and Tang P. (2007) Exploring the "value" of academic patents: IP management practices in UK universities and their implications for Third Stream indicators. Scientometrics, 70, 415-440.

Meyer, M.; with Elena Castro-Martinez, Izabela Kijenska, Basak Candemir, Jordi MolasGallart, Puay Tang, et al. (2007), University Patenting and IP Management Approaches in Europe. Report for the European Patent Office, December 2007, 160 pages.

Minshall, T., Druilhe, C. and Probert, D. (2004) The evolution of 'Third Mission' activities at the University of Cambridge: balancing strategic and operational considerations. Paper presented at the 12th High-Tech Small Firms Conference, University of Twente, The Netherlands.

Mowery, D. C. (1998) Collaborative R\&D: how effective is it? . Issues in Science \& Technology, 15, 37-44.

Mowery, D. C., Nelson, R. R., Sampat, B. N., and Ziedonis, A. A. (2001) The growth of patenting and licensing by US universities: an assessment of the effects of the BayhDole act of 1980. Research Policy, 30, 99-119.

Mowery, D. C., and Sampat, B. N. (2005) The Bayh-Dole Act of 1980 and UniversityIndustry Technology Transfer: A Model for Other OECD Governments? Journal of Technology Transfer, 30, 115-127.

Mowery, D. C., Sampat, B. N., and Ziedonis, A. A. (2002) Learning to Patent: Institutional Experience, Learning, and the Characteristics of U.S. University Patents After the Bayh-Dole Act, 1981-1992. Management Science, 48, 73-89.

Mowery, D. C. and Ziedonis, A. A. (2002) Academic patent quality and quantity before and after the Bayh-Dole act in the United States. Research Policy, 31, 399-418.

Muscio, A. (2010) What drives the university use of technology transfer offices? Evidence from Italy. The Journal of Technology Transfer, 35, 181-202.

Nelson, R. R. (2004) The market economy and the scientific commons. Research Policy, 33, 455-471.

Nelson, A. J. (2014). From the ivory tower to the startup garage: Organizational context and commercialization processes. Research Policy, 43(7): 1144-1156.

OECD (2003) Turning science into business. Patenting and licensing at PROs. Paris: OECD.

Rafferty, M. (2008) The Bayh-Dole Act and university research and development. Research Policy, 37, 29-40.

Saragossi, S. and van Pottelsberghe de la Potterie, B. (2003) What Patent Data Reveal about Universities: The Case of Belgium. The Journal of Technology Transfer, 28, 47-51.

Schacht, W.H. (2009) The Bayh-Dole Act: Selected issues in Patent Policy and the Commercialization of Technology. Report 7-5700. Washington, DC: Congressional Research Service.

Schoen, A., Van Pottelsberghe., B., Henkel, J. 2014, Governance typology of universities' technology transfer processes, Journal of Technology Transfer, 39, 435-453.

Sellenthin, M. (2009) Technology transfer offices and university patenting in Sweden and Germany. The Journal of Technology Transfer, 34, 603-620.

Siegel, D.S, Waldman, D., and Link, A. (2003) Assessing the impact of organizational practices on the relative productivity of university technology transfer offices: an exploratory study. Research Policy, 32, 27-48.

Siegel D. S. and Phan H. P. (2005) Analysing the effectiveness of university technology transfer: implications for entrepreneurship education, in Libecap D. G. (Ed.) University Entrepreneurship and Technology Transfer: Process, Design, and Intellectual Property, pp. 1-38. Elsevier, Amsterdam. 
Siepmann, T. (2004) The Global Exportation of the U.S. Bayh-Dole Act. University of Dayton Law Revie, 30, 209-243.

The Economist (2002) Innovation's golden goose. The Economist, 365, 3.

Thursby, J.G., Thursby, M.C. (2002). Who is selling the ivory tower? Sources of growth in university licensing. Management Science 48 (1), 90-104

Van Looy, B., Ranga, M., Callaert, J., Debackere, K., and Zimmermann, E. (2004) Combining entrepreneurial and scientific performance in academia: towards a compounded and reciprocal Matthew-effect? Research Policy, 33, 425-441.

Van Looy, B., Landoni, P., Callaert, J., Van Pottlesberghe., B., Sapsalis, E., \& Debackere, K. (2011). Entrepreneurial effectiveness of European countries: An empirical assessment of antecedents and trade-offs. Research Policy, 40, 553-564.

Van Zeebroeck, N., Van Pottelsberghe, B., \& Guellec, D. (2008). Patents and academic research: a state of the art. Journal of Intellectual Capital, 9, 246-263.

Wallmark, J. T. (1997) Inventions and patents at universities: the case of Chalmers University of Technology. Technovation, 17, 127-139.

Washburn, J. (2005) University Inc: The Corporate Corruption of Higher Education, New York: Basic Books.

Wright, M., Clarysse, B., Mustar, P., Lockett, A. (2008). Academic Entrepreneurship in Europe. UK Edward Elgar, Cheltenham.

Yin, R. K. (2009) Case study research: design and methods, Thousand Oaks: Sage Publications. 
Table 1. Rates of university-owned patents in selected EU countries

\begin{tabular}{llll}
\hline & 2004-2006 & 2001-2003 & 1998-2000 \\
\hline European Union (27 countries) & 1056 & 796 & 573 \\
Euro Area (15 countries) & 756 & 480 & 311 \\
Denmark & 31 & 17 & 5 \\
Germany (including ex-GDR from 1991) & 252 & 135 & 61 \\
Spain & 51 & 32 & 21 \\
France & 117 & 84 & 46 \\
Italy & 78 & 46 & 24 \\
The Netherlands & 68 & 61 & 52 \\
Austria & 25 & 2 & 3 \\
Sweden & 2 & 5 & 5 \\
United Kingdom & 256 & 284 & 245 \\
Norway & 7 & 1 & 1 \\
Switzerland & 79 & 59 & 47 \\
United States & 1265 & 1172 & 1320
\end{tabular}

Source: Geuna and Rossi (2011) Elaboration of Eurostat data 


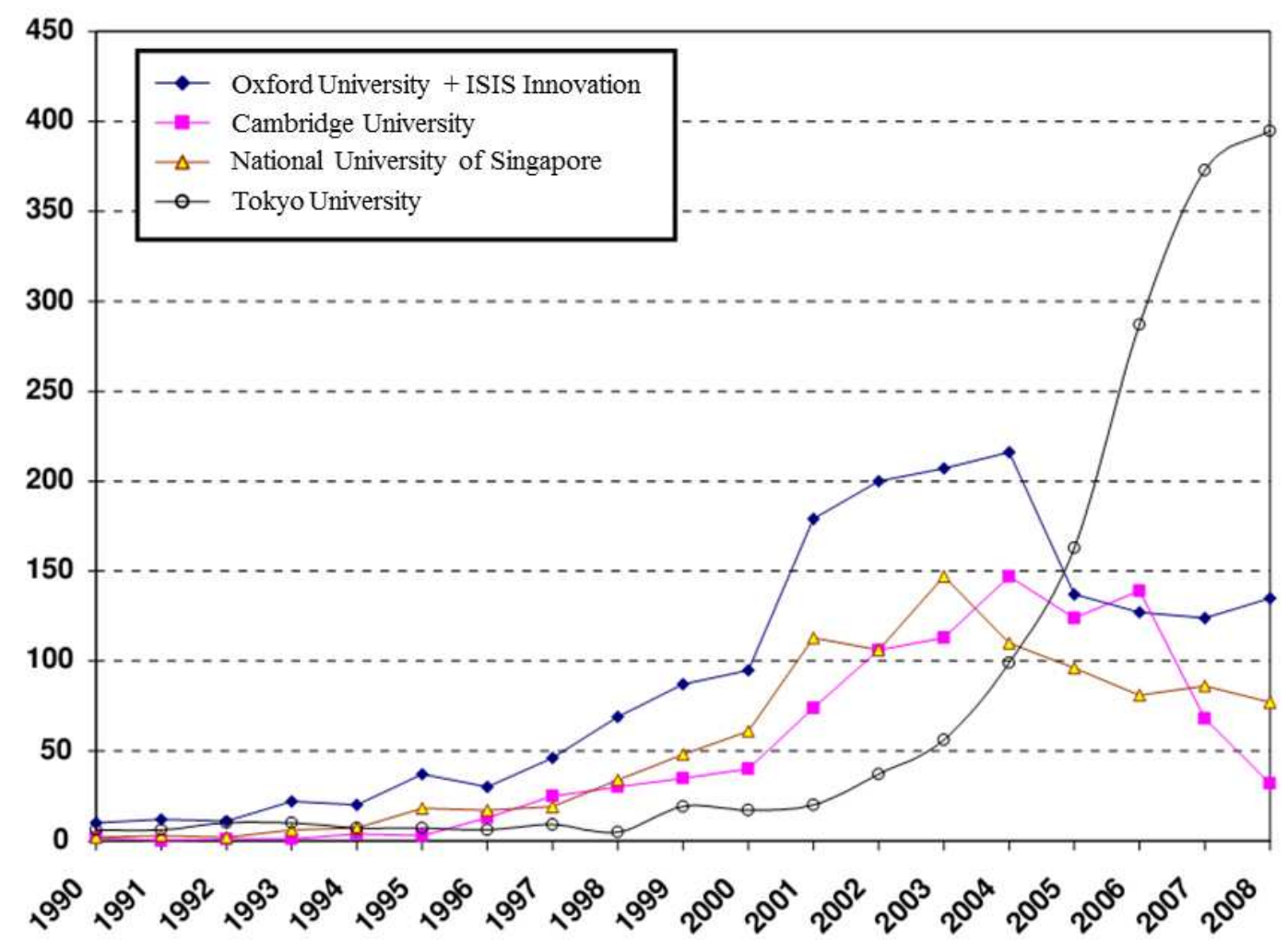

Source: Leydesdorff and Meyer (2010)

Figure 1. Worldwide patents of leading non-US universities (EPO-database) 
Table 2. Key findings from two Spanish universities

\begin{tabular}{|c|c|c|}
\hline $\begin{array}{l}\text { Key } \\
\text { characteristics }\end{array}$ & Universidad de Valladolid & $\begin{array}{l}\text { Universidad de Santiago de } \\
\text { Compostela }\end{array}$ \\
\hline Size indicators & $\begin{array}{l}24,400 \text { students }(2010) \\
1,331 \text { full-time academic staff }(2005 / 6) \\
1,445 \text { full-time academic staff }(2010) \\
\text { R\&D income constitutes } 10.1 \% \text { of total } \\
\text { UVA's income of } € 206 \text { million. }\end{array}$ & $\begin{array}{l}25,945 \text { students }(2010) \\
1,460 \text { full-time academic staff }(2005 / 6) \\
1,352 \text { full-time academic staff }(2010) \\
\text { R\&D income constitutes } 7.3 \% \text { of the } \\
\text { total USC's income of } € 208 \text { million }\end{array}$ \\
\hline \multicolumn{3}{|c|}{ Patenting output indicators } \\
\hline $\begin{array}{l}\text { No. of national } \\
\text { patent } \\
\text { applications }{ }^{1} / \text { FTE }\end{array}$ & $\begin{array}{l}0.002 \text { (3 applications in 2006) } \\
0.010 \text { (14 applications in 2010) }\end{array}$ & $\begin{array}{l}0.011 \text { (16 applications in 2006) } \\
0.021 \text { (29 applications in 2010) }\end{array}$ \\
\hline $\begin{array}{l}\text { No. of PCT patent } \\
\text { applications } 1 / \text { FTE }\end{array}$ & $\begin{array}{l}0.000 \text { (0 PCT applications in 2006) } \\
0.003 \text { (5 PCT applications in 2010) }\end{array}$ & $\begin{array}{l}0.011 \text { (5 PCT applications in 2006) } \\
0.008 \text { (11 PCT applications in 2010) }\end{array}$ \\
\hline $\begin{array}{l}\text { No. of active patent } \\
\text { families/ FTE }\end{array}$ & $\begin{array}{l}0.045 \text { (60 patent families in } 2006) \\
0.068 \text { (98 patent families in } 2010)\end{array}$ & $\begin{array}{l}0.096 \text { (140 patent families in } 2006) \\
0.165 \text { (223 patent families in } 2010)\end{array}$ \\
\hline IP income/ FTE & $\begin{array}{l}€ 5.259 \text { in } 2006(€ 7,000) \\
€ 37.37 \text { in } 2010(€ 54,000)\end{array}$ & $\begin{array}{l}€ 52.055 \text { in } 2006(€ 76,000) \\
€ 45.86 \text { in } 2010(€ 62,000)\end{array}$ \\
\hline
\end{tabular}

\section{IP management and exploitation practices}

Strengthened steering core

Expanded developmental periphery internal unit
Situation in 2006: IP policy, in place since 1997, regulates the patenting process and the distribution IP income (60\% for the academic inventors, $10-$ $17 \%$ for their institute or department, the rest for the university) 2007: launch of an active IP policy

1989: Research Results Transfer Office (OTRI) established as an 1997: OTRI transferred to the University's 'General Foundation' Situation in 2006:

- 8 staff in OTRI

- OTRI's activities revolved predominantly around supporting contract research and consultancy - OTRI manages the IP protection process in collaboration with academics, potential clients. - OTRI is not involved in company formation activities.

2007: Science park opened with an incubator

Situation in 2010:

- 17 staff in OTRI

- OTRI manages proof-of-concept fund

- OTRI implemented a IP management system in 2010.
Situation in 2006: IP policy, in place since 1989, regulates the patenting process and the distribution IP income (60\% for the academic inventors, $20 \%$ for their institute or department, and $20 \%$ for the university).

2012: contribution to socio-economic development is part of strategy for 2011 2020

1989: Research Results Transfer Office (OTRI) established as an internal unit 1999: incubator UNINOVA founded Situation in2006:

- 31 staff in OTRI

- OTRI's activities revolved around all main knowledge transfer mechanisms

- OTRI manages the IP protection process in collaboration with academics, clients.

- OTRI has a structured approach to company formation since 2000.

2008: Science park opened with its own incubator

Situation in 2010:

- 27 staff in OTRI

- OTRI works closely with UNIRISCO

(a venture capital group) and UNINOVA

- OTRI manages proof-of-concept fund

Note: ${ }^{1}$ Source: OEPM. www.oepm.es 
Table 3. Key findings from two German universities

\begin{tabular}{|c|c|c|}
\hline $\begin{array}{l}\text { Key } \\
\text { characteri } \\
\text { stics }\end{array}$ & Technical University of Berlin & Technical University Munich \\
\hline $\begin{array}{l}\text { Size } \\
\text { indicators }\end{array}$ & $\begin{array}{l}312 \text { Professors }(2006) \\
324 \text { Professors }(2011) \\
\end{array}$ & $\begin{array}{l}440 \text { Professors }(2006) \\
487 \text { Professors }(2011) \\
\end{array}$ \\
\hline \multicolumn{3}{|c|}{ Patenting output indicators } \\
\hline $\begin{array}{l}\text { No. of } \\
\text { patents/10 } \\
\text { FTE }\end{array}$ & $\begin{array}{l}\text { - Electrical Engineering/IT: } \\
\text { 1.6(2006)/2.4 (2011) } \\
\text { - Machine building \& Process } \\
\text { engineering: } 0.8(2006) / 2.1(2011) \\
\text { - Chemistry: } 0.41^{*}(2006) / 0.6(2009) \\
\text { - Physics: } 0.28^{*}(2006) / 1.1(2009)\end{array}$ & $\begin{array}{l}\text { - Electrical Engineering/IT: } \\
2.7(2006) / 2.9(2011) \\
\text { - Machine building \& Process engineering: } \\
1.5(2006) / 2.7(2011) \\
\text { - Chemistry: } 0.73^{*}(2006) / 1.1(2009) \\
\text { - Physics:0.51*(2006)/0.71(2009) }\end{array}$ \\
\hline \multicolumn{3}{|c|}{ IP management and exploitation practices } \\
\hline $\begin{array}{l}\text { Strengthen } \\
\text { ed steering } \\
\text { core }\end{array}$ & $\begin{array}{l}\text { - The university has gone through a } \\
\text { process of strategic change more } \\
\text { recently ( } 2005 \text { onwards) } \\
\text { - IP policy ( } 30 \% \text { gross revenue for } \\
\text { inventors and } 70 \% \text { to TUB) } \\
\text { - Knowledge Transfer features in } \\
\text { TUB's mission from } 2001 \\
\text { - Strategic plan for 2013-2020 } \\
\text { commits to promoting technology } \\
\text { transfer and developing } \\
\text { departmental strategies }\end{array}$ & $\begin{array}{l}\text { - The university has gone through a process of change } \\
\text { since } 1995 \text {, revisited its management structure and } \\
\text { general orientation } \\
\text { - IP policy specifying revenue sharing effective Jan } \\
2010 \text { (for inventions: } 30 \% \text { gross revenue for inventors; } \\
\text { the remaining is split between TUM, Chair/Institute } \\
(50 \%) \text { and (if applicable) the Bayerische Patentallianz } \\
\text { GmbH) } \\
\text { - 'TUM. The Entrepreneurial University' strategy was } \\
\text { launched (phase } 1: 2006-11 \text {, phase } 2: 2012-2017 \text { ) }\end{array}$ \\
\hline $\begin{array}{l}\text { Expanded } \\
\text { developme } \\
\text { ntal } \\
\text { periphery }\end{array}$ & $\begin{array}{l}\text { - First incubator in Germany } \\
\text { established at TU Berlin (mid } \\
\text { 1980s) } \\
\text { - IPAL - Patent Commercialization } \\
\text { Agency of the Berlin Universities } \\
\text { (est. 2001), offering IP and market } \\
\text { assessment, IPR counselling and } \\
\text { management, marketing, } \\
\text { licensing/IP sales } \\
\text { - Centre for Entrepreneurship - an } \\
\text { incubator at TU Berlin (est. 2009) } \\
\text { - Internal Patent and Exploitation } \\
\text { office (Patent- und } \\
\text { Verwertungsmanagement) (est. } \\
\text { 2013) }\end{array}$ & $\begin{array}{l}\text { - TUMTech GmbH (est. 1998) - a university company } \\
\text { specializing in analyzing industry needs, exchange of } \\
\text { technology and knowledge between academia and } \\
\text { industry and fundraising } \\
\text { - Internal TUM Patent and Licensing Office (formerly } \\
\text { the TUM-inventor offices, est. Sep 2000) offering } \\
\text { legal and IPR counselling, IP and market assessment, } \\
\text { financing, contracts negotiations, and IP exploitation } \\
\text { (since } 2007 \text { in collaboration with The Bayerische } \\
\text { Patentallianz GmbH) } \\
\text { - The Center for Innovation and Business Creation } \\
\text { (UnternehmerTUM GmbH, est. 2002) helps faculty } \\
\text { and students to start new business ventures } \\
\text { - access to Garching Technology and Business } \\
\text { Incubator (GATE, est. 2002) } \\
\text { - TUM works with The Bayerische Patentallianz } \\
\text { GmbH (est. 2007) offering IP and market assessment, } \\
\text { IPR counselling and management, financing, } \\
\text { marketing, licensing/IP sales } \\
\text { - Internal Industry Liaison Office (est.2010) - helps } \\
\text { faculty to identify and establish contacts with industry, } \\
\text { funders and investors and negotiates contracts } \\
\text { - centers of excellence founded by TUM together with } \\
\text { industry (e.g. CKI in 2001, iniTUM in 2003, } \\
\text { Kompetenzzentrum Mittelstand in 2010) }\end{array}$ \\
\hline $\begin{array}{l}\text { Diversific } \\
\text { ation of } \\
\text { funding } \\
\text { base }\end{array}$ & $\begin{array}{l}\text { University has successfully } \\
\text { diversified funding base }\end{array}$ & $\begin{array}{l}\text { Increased considerably the funding base over the past } \\
\text { ten years. } \\
\text { Fundraising more than doubled over ten year period } \\
\text { leading to } 2012 \text {. }\end{array}$ \\
\hline
\end{tabular}

Note: IP income not available. Information on patenting in chemistry and physics for 2006 (highlighted *) is based on invention disclosures rather than patents 
Table 4. Key findings from two Polish universities

\begin{tabular}{|c|c|c|}
\hline Key characteristics & Warsaw University of Technology & Wroclaw University of Technology \\
\hline Size indicators & $\begin{array}{l}36,156 \text { students }(2011) \\
1,401 \text { academic staff FTE }(2005) \\
2569 \text { academic staff FTE }(2011)\end{array}$ & $\begin{array}{l}32,929 \text { students (2011) } \\
1,177 \text { academic staff FTE (2005) } \\
2045 \text { academic staff FTE }(2011)\end{array}$ \\
\hline \multicolumn{3}{|c|}{ Patenting output indicators } \\
\hline $\begin{array}{l}\text { \#national patent } \\
\text { applications } 1 / \text { FTE }\end{array}$ & $\begin{array}{l}0.031 \text { (44 applications in } 2005) \\
0.018 \text { (46 applications in 2011) }\end{array}$ & $\begin{array}{l}0.042 \text { (49 applications in 2005) } \\
0.098 \text { (201 applications in 2011) }\end{array}$ \\
\hline \multicolumn{3}{|c|}{ IP management and exploitation practices } \\
\hline $\begin{array}{l}\text { Strengthened } \\
\text { steering core }\end{array}$ & $\begin{array}{l}\text { Situation in 2005/6: lack of clear } \\
\text { university policies and strategy in } \\
\text { relation to technology transfer. } \\
\text { (licensing policy from } 2003 \text { made } \\
\text { inventors' income negotiable, the } \\
\text { balance was split between the } \\
\text { department ( } 80 \% \text { ) and the university } \\
(20 \%) \text { ) } \\
\text { Situation in 2011/12: Knowledge } \\
\text { transfer is part of university's } \\
\text { strategic plan for 2011-2020. } \\
\text { IP policy introduced in } 2012 \\
\text { specifies commercialization } \\
\text { procedures and distribution of } \\
\text { income from IP exploitation }\end{array}$ & $\begin{array}{l}\text { Situation in 2005/6: IP policy in place } \\
\text { since } 1998 \text {. Inventors receive } 40 \% \text { of } \\
\text { income from royalties; the remaining is } \\
\text { shared by the inventor's school }(20 \%) \text { and } \\
\text { the university }(20 \%) \text {. } \\
\text { 2008: IP policy review - the inventors' } \\
\text { share of royalty income increases to } 60 \% \\
\text { Situation in 2011/12:Commercialization } \\
\text { of research results is part of the } \\
\text { university's strategic plan and its mission } \\
\text { statement published in } 2013 \text {. }\end{array}$ \\
\hline $\begin{array}{l}\text { Expanded } \\
\text { developmental } \\
\text { periphery }\end{array}$ & $\begin{array}{l}\text { Situation in 2005/6: WUT-based } \\
\text { Technology Transfer Centre, (est. } \\
\text { 2004, formerly part of a research } \\
\text { office since 1999) - contracts } \\
\text { preparation and negotiation, IPR } \\
\text { counselling Reactive approach. } \\
\text { 2010: TTC is merged with a unit } \\
\text { supporting the engagement with } \\
\text { regional companies to form the } \\
\text { Centre for Technology Transfer and } \\
\text { Entrepreneurship Development } \\
\text { (CTTED). } \\
\text { Situation in 2011/12: An incubator } \\
\text { centre is to be opened in 2012. } \\
\text { CTTED has (1) a more proactive } \\
\text { approach; (2) some in-house } \\
\text { capability for assessing invention } \\
\text { patentability and initial estimation of } \\
\text { the market potential; (3) a clear } \\
\text { invention disclosure process; (4) } \\
\text { started developing a network of } \\
\text { faculties-based Enterprise Managers; } \\
\text { (5) very limited experience in } \\
\text { company formation. }\end{array}$ & $\begin{array}{l}\text { Situation in 2005/06: } \\
\text { - WrUT-based non-profit WCTT (est. } \\
\text { 1996) providing legal and IPR } \\
\text { counselling, help with commercialisation } \\
\text { and financing. } \\
\text { - WrUT-based 'Office of Intellectual } \\
\text { Property and Patent Information' - } \\
\text { contracts preparation and negotiation, IPR } \\
\text { counselling (est.2008, formerly part of a } \\
\text { research office since1998) } \\
\text { 2006: Foundation of 'Academic Incubator } \\
\text { of Entrepreneurship' for student, alumni } \\
\text { and staff start-ups and spin-outs. } \\
\text { Situation in 2011/12: OIP\&PI have taken } \\
\text { on additional activities, such as occasional } \\
\text { competitive bids encouraging invention } \\
\text { disclosures, a creation of a database of } \\
\text { technology offers and technology requests } \\
\text { and provision of match-making service. }\end{array}$ \\
\hline $\begin{array}{l}\text { Diversification of } \\
\text { funding base }\end{array}$ & $\begin{array}{l}\text { 2011/12: about } 75 \% \text { of research is } \\
\text { publicly funded }\end{array}$ & $\begin{array}{l}\text { 2011/12: about } 50 \% \text { of research is } \\
\text { publicly funded }\end{array}$ \\
\hline
\end{tabular}

Note. ${ }^{1}$ Source: Intellectual Property Office in Poland 
Table 5. Key findings from two Swedish universities

\begin{tabular}{|c|c|c|}
\hline $\begin{array}{l}\text { Key } \\
\text { characteristics }\end{array}$ & Lund University & Uppsala University \\
\hline $\begin{array}{l}\text { Size indicators } \\
\text { in } 2010 / 11\end{array}$ & $\begin{array}{l}39,448 \text { students } \\
2,736 \text { teaching and research staff (FTE) }\end{array}$ & $\begin{array}{l}34,880 \text { students } \\
2,501 \text { teaching and research staff (FTE) }\end{array}$ \\
\hline \multicolumn{3}{|c|}{ Patenting output indicators } \\
\hline $\begin{array}{l}\text { EU patent } \\
\text { applications }{ }^{1}\end{array}$ & $\begin{array}{l}16(1991-2000) \\
70(2001-2011)\end{array}$ & $\begin{array}{l}12(1991-2000) \\
8(2001-2011)\end{array}$ \\
\hline \multicolumn{2}{|c|}{ No. of companies in } & $\begin{array}{l}31(2005) \\
42(2011)\end{array}$ \\
\hline \multicolumn{3}{|c|}{ IP management and exploitation practices } \\
\hline $\begin{array}{l}\text { Strengthened } \\
\text { steering core }\end{array}$ & $\begin{array}{l}\text { 2007: Increasing collaboration with } \\
\text { industry, patenting and support for } \\
\text { innovation were a part of the university's } \\
\text { strategic plan for } 2007-11 \text {. } \\
\text { 2012: In the strategic plan for } 2012-16 \text { the } \\
\text { university committed developing a better } \\
\text { support infrastructure for knowledge } \\
\text { transfer }\end{array}$ & $\begin{array}{l}\text { 2007: In the strategic plan of } 2007 \text { the } \\
\text { university pledged to 'play an active role in } \\
\text { global society, promoting development and } \\
\text { innovation' but no concrete strategies were } \\
\text { specified. } \\
\text { 2012: Strategic Research plan for } 2013-2016 \\
\text { commits to promoting innovation }\end{array}$ \\
\hline $\begin{array}{l}\text { Expanded } \\
\text { developmental } \\
\text { periphery }\end{array}$ & $\begin{array}{l}\text { Situation in 2006: } \\
\text { - University connected to Ideon - a } \\
\text { business incubator (est. 1983) } \\
\text { - University Holding Company, LUAB } \\
\text { (est. 1996) - provides legal counselling, } \\
\text { IPR counselling, and financing. } \\
\text { - Forskarpatent i Syd AB (est. 1997) IPR } \\
\text { counselling and commercialization of } \\
\text { patented inventions } \\
\text { - LU Innovation - university internal unit } \\
\text { (est. 2002) - liaison with academic } \\
\text { departments and business development } \\
\text { services, IPR counselling } \\
\text { Situation in 2012: } \\
\text { - Lund University's Innovation System } \\
\text { (LUIS) formed in 2009 by merging LUAB } \\
\text { and LU-Innovation. LUIS raises } \\
\text { awareness of IPRs, advises on } \\
\text { commercialization strategy, helps with } \\
\text { patenting and securing funding for IP } \\
\text { exploitation and offers administrative and } \\
\text { legal support to new companies in the first } \\
2 \text { years. } \\
\text { - 2008 Integrated venture capital funds } \\
\text { - AIMday based on Uppsala University's } \\
\text { concept was introduced in } 2012 \\
\text { - Innovation Office South - collaborative } \\
\text { regional project set up in } 2009 \text {; provides } \\
\text { early stage funding } \\
\text { - Forskarpatent i Syd AB - continues to } \\
\text { provide the same support }\end{array}$ & $\begin{array}{l}\text { Situation in 2006: } \\
\text { - University Holding Company, UUAB, } \\
\text { (est.1996): legal counselling, IPR } \\
\text { counselling, and financing. } \\
\text { - Forskarpatent i Uppsala AB (est. 1997, } \\
\text { owned partly by UUAB) IPR counselling and } \\
\text { commercialization of patented inventions } \\
\text { - Uppsala Innovation Centre (UIC) } \\
\text { established in } 2000 \text { - business incubator } \\
\text { (owned partly by UUAB and Forskarpatent) } \\
\text { Situation in 2012: } \\
\text { - Uppsala University Innovation - internal } \\
\text { administrative unit of the university } \\
\text { established in } 2007 \text { (25 staff in 2012), } \\
\text { includes UUAB. It helps researchers with IP } \\
\text { protection, contracts, and fund sourcing and } \\
\text { acts as a gateway for companies interested in } \\
\text { working with the University } \\
\text { - Academia-Industry Meeting Day (AIMday) } \\
\text { created by Angström Materials Academy at } \\
\text { Uppsala University in } 2008 \\
\text { - Innovation Office Uppsala - government } \\
\text { funded, collaborative regional project set up } \\
\text { in } 2009 \\
\text { - Forskarpatent i Uppsala AB and the UIC } \\
\text { continue to provide the same support and } \\
\text { collaborate with Uppsala University }\end{array}$ \\
\hline $\begin{array}{l}\text { Diversification } \\
\text { of funding base }\end{array}$ & $\begin{array}{l}\text { Percentage of income from private sector: } \\
17 \%(2001) \\
17 \%(2009)\end{array}$ & $\begin{array}{l}\text { Percentage of income from private sector: } \\
17 \%(2001) \\
15 \%(2009)\end{array}$ \\
\hline
\end{tabular}

Note. ${ }^{1}$ These are applications filed with EPO by Forskarpatent i Syd and Forskarpatent i Uppsala (Source: Espacenet). Note that Forskarpatent i Syd is associated with 4 higher education institutions, of which Lund University is the largest. 
Table 6. Legislative frameworks in four selected countries

\section{National Legislation}

Patenting in 2000s $\mathrm{s}^{1}$

Sweden 'Professor's privilege' legislation since 1949

The Rights to Employee's Inventions Act of 1949 affirms institutional ownership of IP created by employees but an exemption applying to universities grants Swedish university faculty the right to own intellectual property resulting from publicly funded research.

Spain Institutional IP ownership legislation since 1986

The University Reform Law of 1983 enables university researchers to receive income from commercial organizations. The Patent Law of 1986 affirming institutional ownership of IP created by employees applies to also to universities. The Science Technology and Innovation Law of 2011 obliges public sector employees to make invention disclosures and collaborate in

UL outperforms UU

\section{USC} outperforms UVA commercialisation.

\begin{tabular}{|c|c|}
\hline Institutional IP ownership legislation since in 2002 & \\
\hline $\begin{array}{l}\text { In } 2002 \text { an exemption applying to university faculty was removed from the Employee Invention } \\
\text { Law affirming institutional ownership of IP created by employees. The Higher Education } \\
\text { Framework of } 2005 \text { obliges universities to promote technology transfer. }\end{array}$ & $\begin{array}{l}\text { slightly } \\
\text { outperforms } \\
\text { TUB }\end{array}$ \\
\hline Poland $\quad$ Institutional IP ownership legislation since 1993 & \\
\hline $\begin{array}{l}\text { 1993's Act about Changes to the Inventiveness Law establishes institutional ownership of IP } \\
\text { created by employees (no exemption for university faculty). The Industrial Property Law of } \\
2000 \text { does not deem scientific discoveries unpatentable. The Higher Education Act of } 2005\end{array}$ & $\begin{array}{l}\text { WrUT } \\
\text { outperforms } \\
\text { WUT }\end{array}$ \\
\hline
\end{tabular}
Note. $^{1}$ For details see Tables 2-5. 

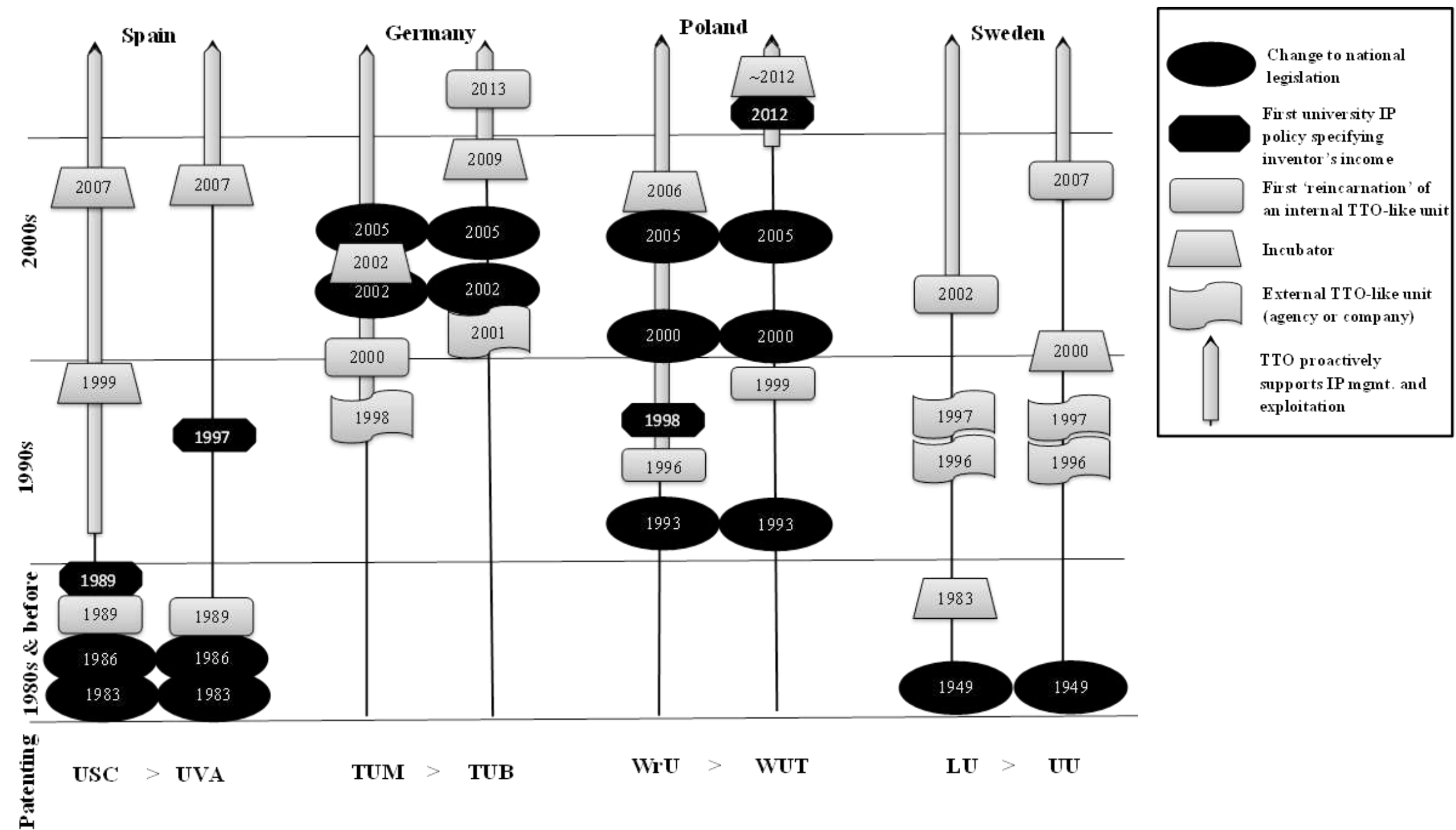

Figure 2. Evolution of local practies and legislative frameworks in selected cases 
Appendix - Template for data collection

\begin{tabular}{|l|l|l|}
\hline \multicolumn{1}{|l|}{ Key Characteristics } & \multirow{2}{*}{ Case 1 } & Case 2 \\
\hline \multicolumn{1}{|l|}{ General indicators } & & \\
\hline Size (Students number) & & \\
\hline Staff (full time professors) & & \\
\hline \multicolumn{1}{|l|}{ IP Management } & \\
\hline $\begin{array}{l}\text { IP Framework } \\
\text { [brief description] }\end{array}$ & & \\
\hline Active Patent Portfolio Management? & \\
\hline $\begin{array}{l}\text { Approach to generating invention disclosures from academics } \\
\text { [brief description] }\end{array}$ & \\
\hline $\begin{array}{l}\text { Incentive System for Academic Inventors (royalty sharing) } \\
\text { [brief description] }\end{array}$ & \\
\hline $\begin{array}{l}\text { General entrepreneurial outlook of HEI } \\
\text { [Brief description, perhaps broadly follow Burton Clark's 5 elements } \\
\text { (strengthened steering core, diversified funding base, Developmental } \\
\text { periphery, stimulated heartland, entrepreneurial culture); otherwise } \\
\text { general judgement: entrepreneurial vs traditional }\end{array}$ & & \\
\hline $\begin{array}{l}\text { Output \& Impact Indicators } \\
\text { Level of University Patenting } \\
\text { If possible: numbers [\# new patents applied or granted per year, type of } \\
\text { patent] }\end{array}$ & & \\
\hline Value of portfolio & & \\
\hline Income from licenses & & \\
\hline Number of university spin outs & & \\
\hline Science parks/ incubators & & \\
\hline Employment impact / growth & & \\
\hline Perceived impact on regional development & \\
\hline
\end{tabular}

